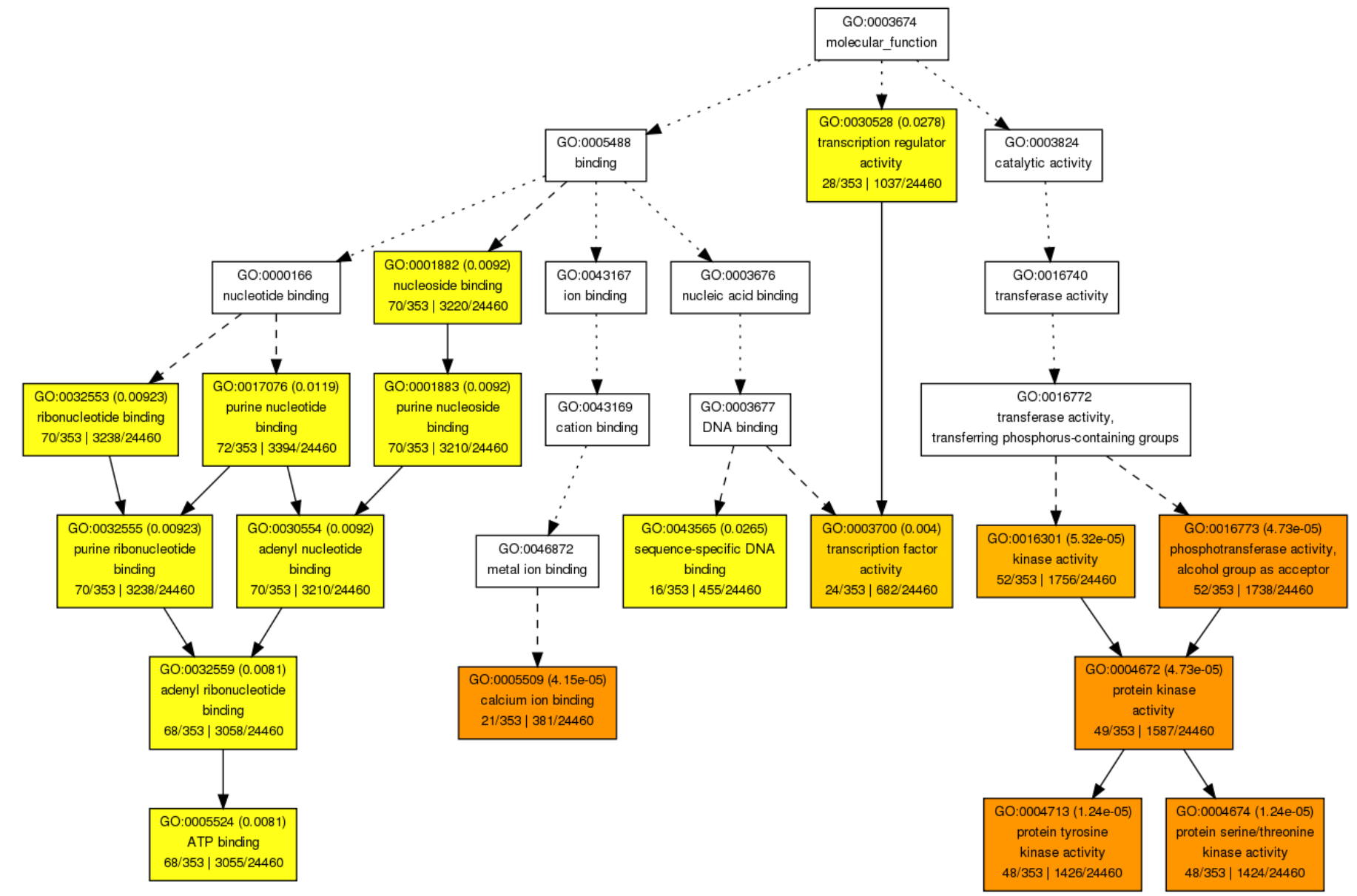

\title{
Significance levels
}

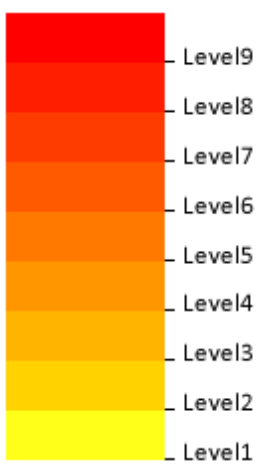




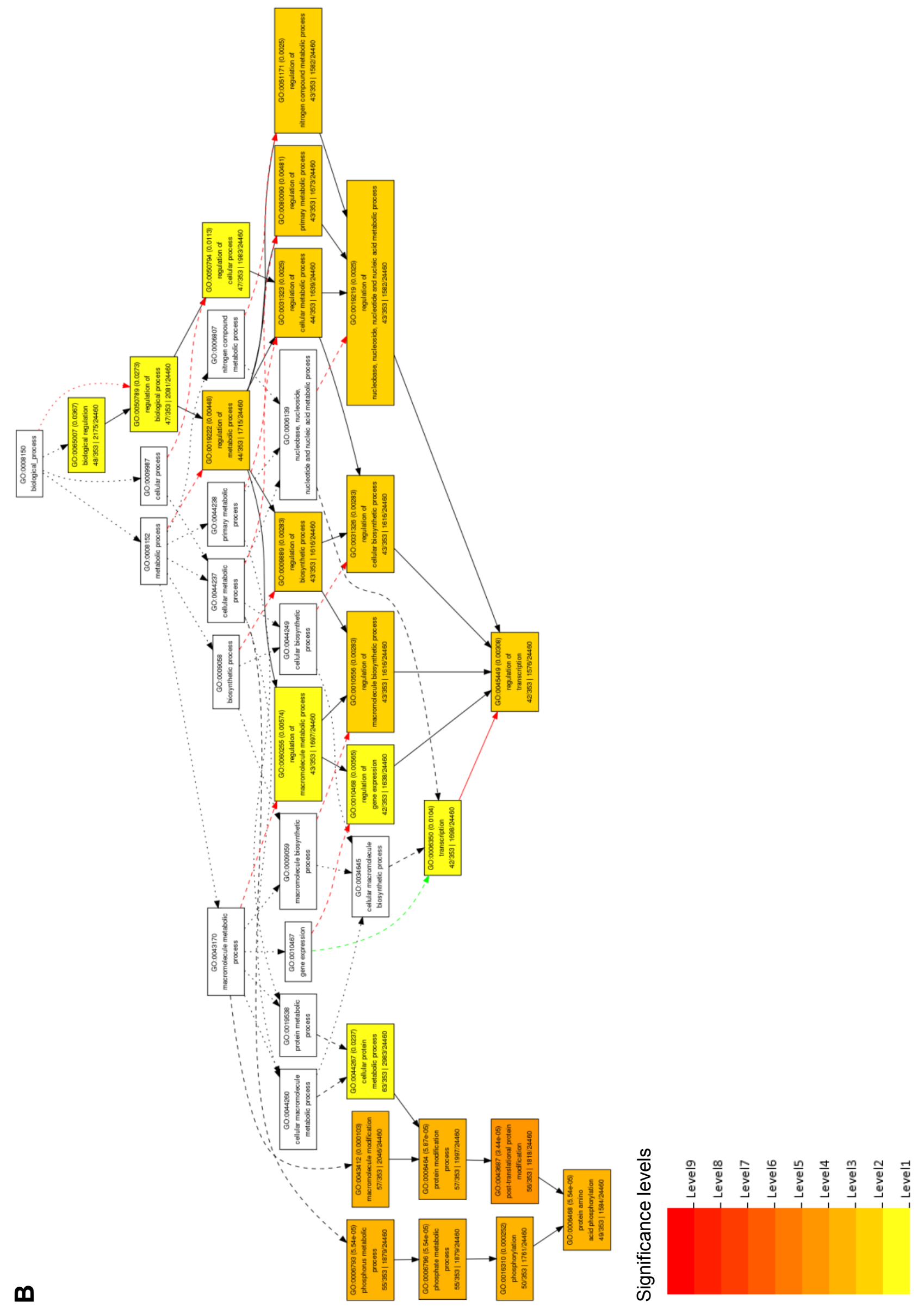


C

GO:0005575

cellular_component

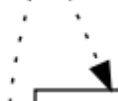

GO:0005623

cell

Significance levels

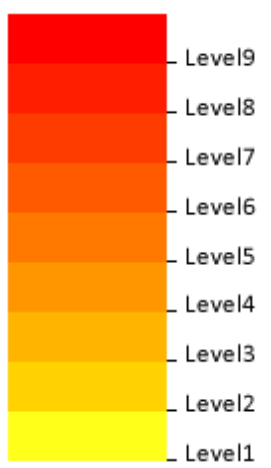

GO:0016020 (0.0213)

membrane 52/353 | 2185/24460 